\title{
Prevention of crime by criminal law and operational-search means
}

\author{
Anna Pavlovna Alekseeva ${ }^{11}$, Sergey Vladimirovitch Veklenko ${ }^{2}$, Aleksander Ivanovitch \\ Melikhov ${ }^{3}$, Galina Nickolaevna Mironova ${ }^{4}$, and Aleksander Aleksandrovitch Turyshev ${ }^{4}$ \\ ${ }^{1}$ Kaliningrad branch of the St. Petersburg University of the Russian Ministry of Internal Affairs, \\ Department of Criminal Law, Criminology and Penal Law, Kaliningrad, Russia \\ ${ }^{2}$ Kaliningrad branch of the St. Petersburg University of the Russian Ministry of Internal Affairs, \\ Kaliningrad, Russia \\ ${ }^{3}$ Volgograd Academy of the Russian Ministry of Internal Affairs, Department of Constitutional and \\ Administrative Law, Volgograd, Russia \\ ${ }^{4}$ Omsk Academy of the Russian Ministry of Internal Affairs, Department of Criminal Law, Omsk, \\ Russia
}

\begin{abstract}
In the early 2000s, the Russian legislator massively introduced the term "preventing crime" into regulations thus replacing the concept of "fighting against crime". Thus, the changes influenced federal law No. 130-FZ "Combating Terrorism" dated 25 July 1998 and many other laws. The very concept of the state's response to violation of the established prohibitions has changed. If in the old version of the laws, punishment for committing a crime was the main preventive measure, then in the new understanding the key efforts of the state should have been focused on preventing the very event of a crime. On the one hand, this is an absolutely correct step, since it is much more profitable for the state (in socio-economic, political and other respects) to keep the population from violating the established rules than to be forced to launch a complex and expensive criminal procedural mechanism (to identify, disclose, investigate crimes, consider them in court, execute punishment, etc.). On the other hand, in the new laws, the term "prevention" is used ambiguously, to both characterise "crime prevention" activities and characterise "crime control" activities. The research objective is to find the most optimal ways to eliminate theoretical and practical contradictions arising from the law enforcement in connection with the tautology of the texts of federal laws in the field of combating crime. In the course of the research, the dialectical method of cognition was used, as well as general scientific (analysis and synthesis, induction and deduction, logical, systemic and structural methods) and specific scientific methods of cognition (historical, statistical and formal-legal). It is proposed to unify the definition of "combating crime" by introducing the same definitions into the federal law "Operational Investigative Activity", "Countering Terrorism", and other regulatory documents related to "combating crime".
\end{abstract}

Keywords: legislative terminology, law enforcement problems, crime prevention, combating crime

\footnotetext{
${ }^{1}$ Corresponding author: alexeeva.klg-mvd@yandex.ru
} 


\section{Introduction}

Changes in the social and political system in the 1990s in Russia inevitably affected all legislation which was supposed to reflect the realities of that time. The sharp increase in crime forced the legislator to respond with the adoption of the laws on crime control issues.

Federal law No. 144-FZ "Criminal Intelligence Activities" dated 12 August 1995 laid the foundations for this work by enshrining detection, prevention, suppression and solution of crimes among the priorities of the staff of criminal intelligence unit. Upon closer examination, it becomes clear that the detection, suppression and solution of crimes refer to activities against an already committed crime, while prevention should be implemented before crime begins. Otherwise, the goals of prevention (keeping a person from violating the established prohibition) will not be achieved [1,2].

A similar situation manifested itself in the text of federal law No. 130-FZ "Fight against Terrorism" dated 25 July 1998 (currently not valid). The "fight against terrorism" was understood as "activities to prevent, identify, suppress and minimise the consequences of terrorist activities" in the law. Although it is quite obvious that it is possible to "fight" with only crimes already in place, committed $[3,4]$. Otherwise, those activities make no sense. When no prohibitions are violated, then there is nothing to identify, suppress and/or minimise $[5,6]$. In 2006, the old law was replaced by a new one, namely the federal law No. 35-FZ "Countering Terrorism" dated 06 March 2006. It changed the very concept of the state's response to the violation of established prohibitions, now terrorism had to be countered, while the fight became only part of the operations. So, based on the definition in Article 3 of the federal law No. 35-FZ, we can conclude that "countering terrorism" includes "prevention of terrorism", which consists of preventing terrorism, identifying and eliminating the causes and conditions conducive to the commission of terrorist acts, and also the fight against terrorism, that is the identification, prevention, suppression, solution and investigation of a terrorist act. The term "prevention", according to the legislator, can simultaneously reflect the meaning of actions designed to prevent and combat terrorism, which contradicts all conceivable laws of logic.

\section{Methods}

It should be noted that this situation has become a tradition in Russian legislative drafting. In the adopted regulatory documents, the legislator either failed to interpret the term "counteraction" at all (in the federal law No. 115-FZ "Counteracting the Legalisation (Laundering) of Criminally Obtained Incomes and Financing of Terrorism" dated 07 August 2001), or used the term "prevention" to characterise both "prevention" and "fight" (in the federal laws No. 114-FZ "Countering Extremist Activities" dated 25 July 2002, No. 273-FZ "Countering Corruption" dated 25 December 2008, and others). Only in 2011, with the adoption of the federal law No. 3-FZ "Police" dated 07 February 2011, the situation in the legislation began to progress. Having enshrined in Article 1 the provision that the police is intended to combat crime, in Article 2 the legislator outlined the key activities, such as prevention and suppression of crimes and administrative offences; detection and solution of crimes, holding inquests in criminal cases.

\section{$3 \quad$ Results}

It is believed that Russian legislation needs to be corrected in terms of the unification of terminology related to combating crime. Based on the foregoing, it would be most correct to consider "combating crime" as a term that unites all the activities. Prevention should 
become relevant when it comes to a potential but not yet conceived crime (prevention) [7-9]; about a crime conceived and prepared but not yet committed at the stage of preparation (prevention) $[10,11]$; about a crime started but still unfinished at the stage of attempt (suppression) [12]. If a crime is over, then it is time to carry out measures to combat (identification, disclosure, investigation, etc.) [13-15]. Such an arrangement should be stated in all regulatory documents related to combating crime without exception.

\section{Discussion}

The implementation of our proposals will make it possible to more clearly understand the essence of combating crime in general. If we proceed from the option we have stated, it will become obvious that the existing Criminal Code of the Russian Federation (hereinafter the Criminal Code of the Russian Federation), as well as the federal law No. 144-FZ "Criminal Intelligence Activities" dated 12 August 1995, have the most significant preventive potential.

The Criminal Code of the Russian Federation, as a source of substantive law, contains a list of behaviours that are prohibited under the threat of applying measures of liability. It is believed that the very threat of applying liability measures carries a powerful preventive charge. A person mindful of the fact that that he/she can be punished voluntarily refuses illegal behaviour and chooses the lawful one. If a person still violated the prohibition established by the code, he/she is brought to justice, and here implemented is a secondary warning enshrined as the purpose of punishment in Article 43 of the Criminal Code of the Russian Federation, "Punishment is applied in order to restore social justice, as well as to correct the convicted person and prevent committing new crimes". Having once experienced repression from the state for disobedience and non-observance of the established prohibitions, a person should realise all the erroneousness of his/her choice and no longer repeat it.

The problem is that citizens, due to their legal illiteracy, for the most part, cannot always clearly distinguish between legal and illegal behaviour prohibited by the Criminal Code of the Russian Federation. Often, "universal human positions" do not meet the opinion of the legislator about proper behaviour. When it comes to behaviour, that has been unacceptable since biblical times, "universal human positions" are fully consistent with the provisions of the Criminal Code of the Russian Federation; everyone understands that you cannot kill, steal, etc. But when it is necessary to designate, for example, the limits of justifiable defence, heat of passion, etc., then "universal human positions" may differ from the opinion of the legislator. Therefore, while agreeing with the undoubtedly leading positions of the Criminal Code of the Russian Federation as a source of preventive activities, we consider it necessary to refer to another source, namely the federal law No. 144-FZ "Criminal Intelligence Activities" dated 12 August 1995, which allows its means to prevent and suppress illegal actions even before the damage to the protected rights and interests of citizens is done, and before a crime is completed.

Article 7 of the federal law No. 144-FZ provides for criminal intelligence activities to be carried out in the event that the bodies carrying out criminal intelligence activities become aware of the signs of a prepared or committed illegal act, as well as about the persons preparing or committing it, even then, when there is insufficient information to resolve the issue of initiating a criminal case. This suggests that operations officers are empowered to stop potential offenders at the earliest stage, preparations for committing a crime that means prevention of impending crimes. The position of the legislator, in this case, deserves full support, since from the legal side the necessary conditions for conducting criminal intelligence activities can be justified, and the practice has created 
sufficient conditions, the availability of data for carrying out the corresponding criminal intelligence activities.

\section{Conclusion}

The use of uniform terminology in Russian legislation is a necessary step to unify law enforcement practices. The most acceptable way of unification is to codify the criminological and criminal-intelligence legislation. The emergence of the Criminological Code of the Russian Federation and the Criminal-Intelligence Code of the Russian Federation, which scientists have been talking about for decades, can level the problem we have identified. It is clear that the codification of legislation is proceeding very slowly; it is a very difficult and long road. However, we are sure that this will happen sooner or later. Codification will allow law enforcement to more clearly understand and enforce the laws in force in the country.

\section{References}

1. C.B.R. Evans, K.C. Stalker, M.E. Brown, Aggres. Viol. Behav. 56, 101513 (2021). https://doi.org/10.1016/j.avb.2020.101513

2. A. Matsukawa, Sh. Tatsuki, Int. J. Law, Crime and Just. 54, 89-101 (2018). https://doi.org/10.1016/j.ijlcj.2018.03.007

3. A.P. Alexeeva, Crim. J. Baikal National Univ. Econ. Law 1, 77-83 (2014)

4. T.-H. Moon, S.-Y. Heo, S.-H. Lee, Proc. Environ. Sci. 22, 288-301 (2014)

5. A.I. Melikhov, et al., Private investigation services' development to ensure the world attractiveness of russion jurisdiction, in European Proc. Soc. and Behav. Sci. EpSBS. Int. Sci. Conf. dedicated to the 80th anniversary of Turkayev Hassan Vakhitovich, 27-29 February, 2020, 713-720 (Kh. I. Ibragimov Complex Research Institute, Grozniy, 2020). https://doi.org/10.15405/epsbs(2357-1330).2020.10.5

6. H. Wang, S. Ma, Soc.-Econ. Plan. Sci., 101043 (2021). https://doi.org/10.1016/j.seps.2021.101043

7. R.A. Adeyemia, J. Mayakia, T.T. Zewotirb, Sh. Ramroopc, Spatial Stat. 41, 100485 (2020). https://doi.org/10.1016/j.spasta.2020.100485

8. G. Gimenez, B. Barrado, Stud. Edu. Eval. 65, 100867 (2020). https://doi.org/10.1016/j.stueduc.2020.100867

9. M.A. Jalil, F. Mohd, N.M.M. Noor, Procedia Comp. Sci. 116, 113-120 (2017). https://doi.org/10.1016/j.procs.2017.10.018

10. S. Mello, J. Pub. Econ. 172, 174-200 (2019). https://doi.org/10.1016/j.jpubeco.2018.12.003

11. B. Moews, J.R. Argueta Jr., A. Gieschen, Decision Sup. Sys. 144, 113518 (2021). https://doi.org/10.1016/j.dss.2021.113518

12. N.S. Safa, et al., Fut. Gen. Comp. Sys. 97, 587-597 (2019). https://doi.org/10.1016/j.future.2019.03.024

13. E. Krulichová, Int. J. Law, Crime and Just. 65, 100457 (2021). https://doi.org/10.1016/j.ijlcj.2021.100457

14. M. Quick, G. Li, I. Brunton-Smith, J. Crim. Just. 58, 22-32 (2018). https://doi.org/10.1016/j.jcrimjus.2018.06.003 
15. Ch. Cheng, W. Long, J. Pub. Econ. 164(C), 1-18 (2018).

https://doi.org/10.1016/j.jpubeco.2018.05.002 